\title{
Article \\ Significance of the brazing gap in the brazing of aluminium heat exchangers for automotive industry
}

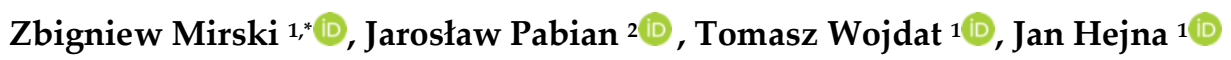 \\ 1 Wrocław University of Science and Technology, Faculty of Mechanical Engineering, Poland; \\ tomasz.wojdat@pwr.edu.pl (T.W.); jan.hejna@pwr.edu.pl (J.H.) \\ 2 MAHLE Behr Ostrów Wielkopolski, Poland; \\ jaroslaw.pabian@pl.mahle.com (J.P.) \\ * Correspondence: zbigniew.mirski@pwr.edu.pl (Z.M.) \\ Received: 01.04.2020; Accepted: 30.05.2020
}

\begin{abstract}
The paper presents the influence of the brazing gap width on the structure of bonded joints during the production of aluminum heat exchangers, using brazing technology, in tunnel furnaces with controlled atmosphere. Based on the wedge test, an analysis and qualitative assessment of brazed joints was made for the changing width of the brazing gap and the filler metal used. For the received brazed joints, metallographic tests were carried out using light (LM) and electron microscopy (SEM) and microhardness measurements in the characteristic areas of brazed joints. Based on the results obtained, the recommended width of the brazing gap was determined.
\end{abstract}

Keywords: aluminum heat exchangers; aluminium alloy; brazing; wedge test; brazing gap; brazed joint microstructure; microhardness

\section{Introduction}

Most of the currently produced heat exchangers in the automotive industry, are made of aluminum alloys [1] using brazing technology in the continuous tunnel furnaces (Fig. 1) [2].

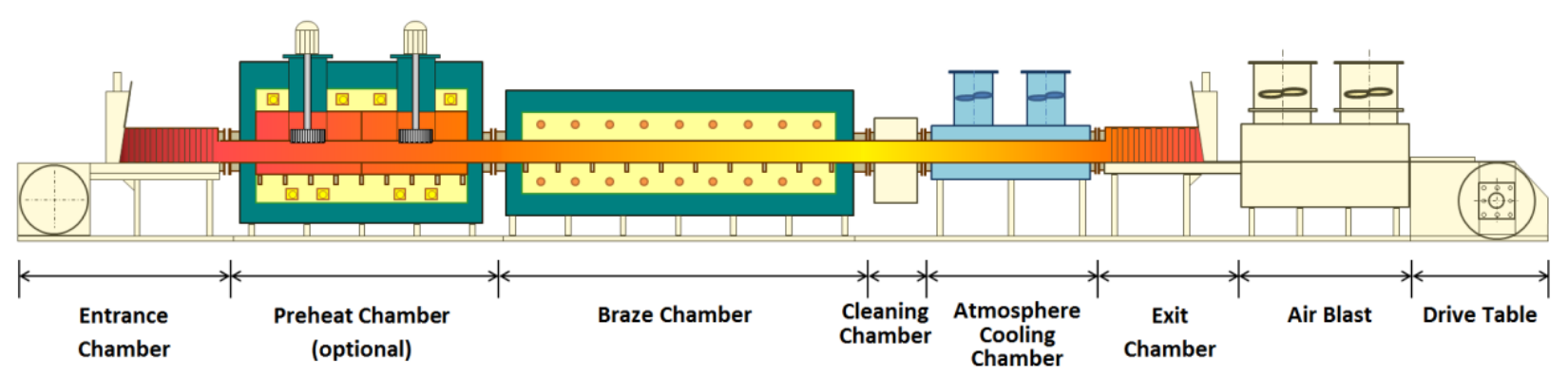

Fig. 1. Continuous tunnel furnace for brazing of aluminum heat exchangers

These alloys are characterized by both better mechanical properties and increased corrosion resistance than pure aluminum. They are well suited for forming process, among others by stamping and rolling and they can be used for operating at elevated temperature [4].

These alloys may have a slight additive of $\mathrm{Mg}$, improves their mechanical properties, but on the other hand (depending on the amount of additive) worsen brazing properties - the wettability of the surfaces of bonded elements deteriorates [1]. Currently, EN-AW3003 and EN-AW3005 alloys are most commonly used in brazing heat exchangers, whose chemical composition is given in Table I.

Generally, the most commonly used is filler metal of subeutectic composition AlSi7.5 and then filler metals AlSi10 and AlSi12, in case when the brazing temperature locally falls (the chemical composition of filler metals is given in Table II). 
Table I. Chemical composition of aluminum alloys used for heat exchangers, according to EN 573-3:2014-02

\begin{tabular}{cccccccccccc}
\hline $\begin{array}{c}\text { Alloy designation } \\
\text { (abbreviated as } \\
\text { chemical symbols) }\end{array}$ & $\mathbf{A l}$ & $\mathrm{Si}$ & $\mathbf{F e}$ & $\mathbf{C u}$ & $\mathbf{M n}$ & $\mathbf{M g}$ & $\mathbf{C r}$ & $\mathbf{N i}$ & $\mathbf{Z n}$ & $\mathrm{Ti}$ & Others \\
\hline EN-AW3003 & reminder & $\div$ & $\div$ & $\div$ & $\div$ & - & - & - & $\div$ & - & each 0.05 \\
(AlMn1Cu) & & 0.60 & 0.70 & 0.20 & 1.50 & & & & 0.10 & total 0.15 \\
\hline EN-AW3005 & & 0.00 & 0.00 & 0.00 & 1.00 & 0.20 & 0.00 & & 0.00 & 0.00 & each 0.05 \\
$($ AlMn1Mg0.5) & reminder & $\div$ & $\div$ & $\div$ & $\div$ & $\div$ & $\div$ & - & $\div$ & $\div$ & total 0.15 \\
& & 0.60 & 0.70 & 0.30 & 1.50 & 0.60 & 0.10 & & 0.25 & 0.10 & \\
\hline
\end{tabular}

Table II. Melting range and recommended range of brazing temperature for filler alloys used for aluminum heat exchangers [5]

\begin{tabular}{cccc}
\hline $\begin{array}{c}\text { Filler alloy designation } \\
\text { (abbreviated as chemical symbols) }\end{array}$ & $\begin{array}{c}\text { Nominal content } \\
\text { of silicon, } \text { wt. } \%\end{array}$ & $\begin{array}{c}\text { Temperature } \\
\text { solidus - liquidus, }{ }^{\circ} \mathbf{C}\end{array}$ & $\begin{array}{c}\text { Recommended range } \\
\text { of brazing temperature, }{ }^{\circ} \mathbf{C}\end{array}$ \\
\hline $\begin{array}{c}\text { EN-AW4343 } \\
(\mathrm{AlSi7.5)}\end{array}$ & 7.5 & $577 \div 613$ & $593 \div 621$ \\
\hline $\begin{array}{c}\text { EN-AW4045 } \\
(\mathrm{AlSi10)}\end{array}$ & 10.0 & $577 \div 591$ & $588 \div 604$ \\
\hline $\begin{array}{c}\text { EN-AW4047A } \\
(\mathrm{AlSi12})\end{array}$ & 12.0 & $577 \div 582$ & $582 \div 600$ \\
\hline
\end{tabular}

The brazeability of the used aluminum alloys is affected by their physicochemical properties. The negative influence has got the high heat expansion, high thermal conductivity and high oxygen affinity with which aluminum forms refractory $\left(2060{ }^{\circ} \mathrm{C}\right)$ and chemically stable oxides [3]. The last one, is a great difficulty because they are not wettable by currently used filler metals. Therefore, the heat exchangers surface to be joined, should be initially cleaned from the oxides and constantly protected during the brazing process, so that they do not oxidize again. The brazing process in furnaces with controlled atmosphere also takes place under the influence of the NOCOLOK flux, which is potassium fluoroaluminate $\mathrm{K}_{1-3} \mathrm{AlF}_{4-6}[1]$.

The basic physicochemical phenomena occurring during brazing are: chemical reduction or dissociation of oxides, melting, capillary phenomena, diffusion and dissolution of components, and crystallization. These phenomena can be grouped in three successive stages that make up the cycle of the brazed being formed [4]:

joint

- activation of the surfaces of the materials to be joined and the molten filler metal,

- interaction at the interface (at the boundary): molten filler metal - material to be joined,

- crystallization of brazing joint.

\section{Model of wedge test}

Carrying out a wedge test enables learning about the effects of many effects of physicochemical phenomena that occur during brazing. It allows the selection of the optimal width of the brazing gap, based on the evaluation of the crystal structure of the bonded joint, especially of the brazing joint. It is also used to determine the capillary capability of the filler metal which is filling the brazing gap of increasing width. Finally, this test makes it possible to make a qualitative and functional assessment of the brazed joint [6].

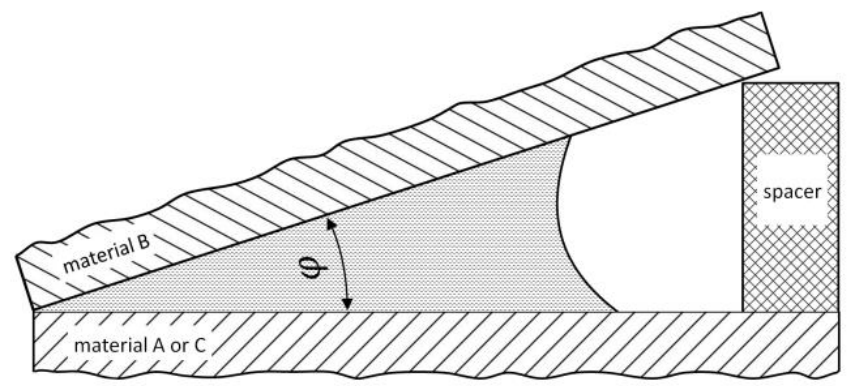

Fig. 2. Diagram of the wedge test after the brazing process 
Figure 2 shows a diagram of a wedge test, for brazing of various materials A, B and C. Material A and $\mathrm{C}$ is cladded by filler metal from the side where the joint with material $\mathrm{B}$ is to be made and additionally NOCOLOK flux is applied on this surface. Application of such a system, due to different coefficients of thermal conductivity and linear expansion of both materials, among others, it can cause non-uniform crystallization of filler material. The heat from the system is dissipated in a direction perpendicular to the surfaces forming the gap and will be removed more quickly from the place where the volume of material is smaller, thus the solidification of the filler metal will begin at the vertex of the wedge test. In the narrow part of the gap, the brazed joint is more exposed to cracks, but to make it happen, it would have to separate hard intermetallic phases, and both brazed materials would have to differ significantly in thermal expansion.

\section{Test methodology and materials}

In order to examine the effect of the used type of core material and filler metal on phenomena that occur during the brazing process, 2 types of joints were made. Specimens were obtained according to the diagram shown in Figure 3.

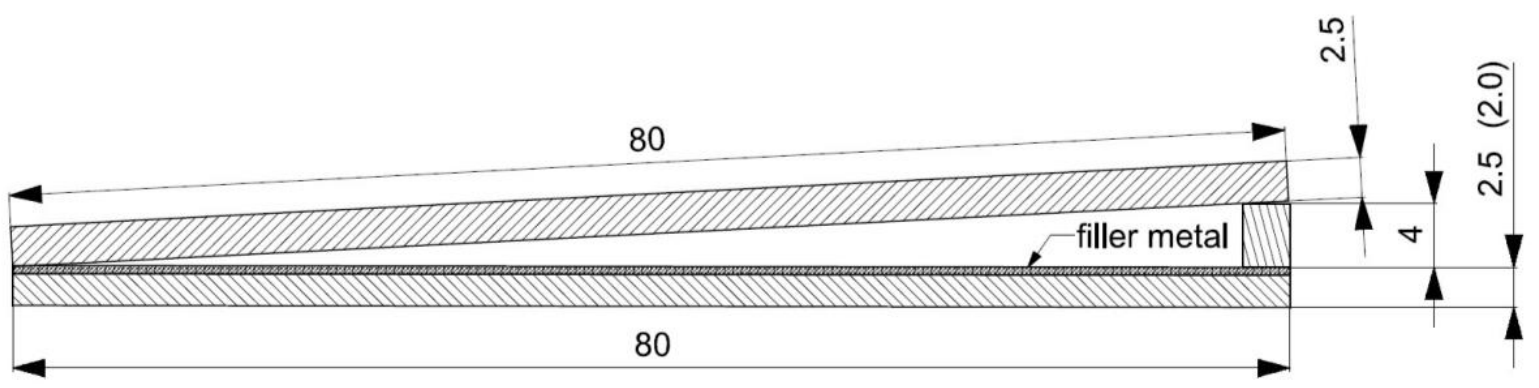

Fig. 3. Diagram of preparation of elements for performance of the wedge test

The data on materials used for the wedge test are given in Tables III, IV and V. The plates measuring $80 \times 25 \times 2.5$ (2.0) mm were used.

Table III. Data on the implementation of the wedge test

\begin{tabular}{cccccc}
\hline Plate designation & $\begin{array}{c}\text { Plate thickness, } \\
\text { mm }\end{array}$ & $\begin{array}{c}\text { Nominal filler } \\
\text { metal thickness, } \\
\text { \% }\end{array}$ & $\begin{array}{c}\text { Nominal filler } \\
\text { metal thickness, } \\
\text { mm }\end{array}$ & $\begin{array}{c}\text { Type of used } \\
\text { filler metal }\end{array}$ & $\begin{array}{c}\text { Type of used } \\
\text { core material }\end{array}$ \\
\hline $\begin{array}{c}\text { Upper plate } \\
\text { type B }\end{array}$ & 2.5 & 0 & 0 & - & $\begin{array}{c}\text { EN-AW3003 } \\
(\mathrm{AlMn} 1 \mathrm{Cu})\end{array}$ \\
\hline $\begin{array}{c}\text { Lower plate } \\
\text { type A }\end{array}$ & 2.5 & 4.0 & 0.10 & $\begin{array}{c}\text { EN-AW4045 } \\
\text { (AlSi10) }\end{array}$ & $\begin{array}{c}\text { EN-AW3005 modified } \\
(\text { AlMn1CuMg0.05) }\end{array}$ \\
\hline $\begin{array}{c}\text { Lower plate } \\
\text { type C }\end{array}$ & 2.0 & 5.0 & 0.10 & $\begin{array}{c}\text { EN-AW4343 } \\
\text { (AlSi7.5) }\end{array}$ & $\begin{array}{c}\text { EN-AW3005 modified } \\
\text { (AlMn1CuMg0.3) }\end{array}$ \\
\hline
\end{tabular}

Table IV. Chemical composition of the core material of plates used for the wedge test

\begin{tabular}{|c|c|c|c|c|c|c|c|c|c|c|c|}
\hline \multirow{2}{*}{$\begin{array}{c}\text { Plate } \\
\text { designation }\end{array}$} & \multicolumn{11}{|c|}{ Chemical composition, wt. $\%$} \\
\hline & Al & Si & Fe & $\mathrm{Cu}$ & Mn & Mg & $\mathrm{Cr}$ & $\mathrm{Ni}$ & $\mathrm{Zn}$ & $\mathrm{Ti}$ & Others \\
\hline \multirow{3}{*}{$\begin{array}{l}\text { Upper plate } \\
\text { type B }\end{array}$} & \multirow{3}{*}{ reminder } & 0.00 & 0.00 & 0.05 & 1.00 & \multirow{3}{*}{-} & \multirow{3}{*}{-} & \multirow{3}{*}{-} & 0.00 & \multirow{3}{*}{-} & \multirow{3}{*}{$\begin{array}{l}\text { each } 0.05 \\
\text { total } 0.15\end{array}$} \\
\hline & & $\div$ & $\div$ & $\div$ & $\div$ & & & & $\div$ & & \\
\hline & & 0.60 & 0.70 & 0.20 & 1.50 & & & & 0.10 & & \\
\hline \multirow{3}{*}{$\begin{array}{c}\text { Lower plate } \\
\text { type A }\end{array}$} & \multirow{3}{*}{ reminder } & 0.00 & 0.00 & 0.05 & 1.00 & 0.00 & \multirow{3}{*}{-} & \multirow{3}{*}{-} & 0.00 & \multirow{3}{*}{-} & \multirow{3}{*}{$\begin{array}{l}\text { each } 0.05 \\
\text { total } 0.15\end{array}$} \\
\hline & & $\div$ & $\div$ & $\div$ & $\div$ & $\div$ & & & $\div$ & & \\
\hline & & 0.60 & 0.70 & 0.20 & 1.50 & 0.05 & & & 0.10 & & \\
\hline \multirow{3}{*}{$\begin{array}{c}\text { Lower plate } \\
\text { type C }\end{array}$} & \multirow{3}{*}{ reminder } & 0.60 & 0.40 & 0.40 & 1.10 & 0.20 & \multirow{3}{*}{-} & \multirow{3}{*}{-} & 0.00 & \multirow{3}{*}{-} & \multirow{3}{*}{$\begin{array}{l}\text { each } 0.05 \\
\text { total } 0.15\end{array}$} \\
\hline & & $\div$ & $\div$ & $\div$ & $\div$ & $\div$ & & & $\div$ & & \\
\hline & & 0.84 & 0.60 & 0.64 & 1.40 & 0.30 & & & 0.05 & & \\
\hline
\end{tabular}

Table V. Plates configuration for the performed wedge test

\begin{tabular}{ccc}
\hline Designation of the wedge test specimen & Type of lower plate & Type of upper plate \\
\hline A-B & type A & type B \\
C-B & type C & type B \\
\hline
\end{tabular}


The bottom plate was cladded with filler metal, $4-5 \%$ thickness of the plate, i.e. about $0.1 \mathrm{~mm}$. The filler metal (cladded side of plate) was coated with the NOCOLOK flux, applying it using the PaintFlux method, by spray application of the NOCOLOK flux mixture with demineralized water and adhesive material (NOCOLOK Precoating) [7].

Before the flux was applied, the surface of the element was thermally degreased, and no additional treatments were performed to prepare the bonded surfaces. The elements brazed in the wedge test were initially joined with tack welds made using the TIG method, which resulted in the creation of a gap about $0.05 \mathrm{~mm}$ wide at the beginning of wedge. On the other end of wedge (opposite side) was inserted a spacer made of aluminum, whose height was equal to $4 \mathrm{~mm}$. The prepared samples were brazed in a tunnel furnace, under an atmosphere of pure nitrogen (99.999\%) using a relatively short brazing cycle, i.e. about 25 min. In the first phase of the brazing process, which is thermal degreasing, organic compounds were removed (evaporated), this process takes place at a temperature of approx. $250 \div 300{ }^{\circ} \mathrm{C}$. The next stage is the proper brazing process, in which the samples reached the maximum temperature in the range of 604 to 607 ${ }^{\circ} \mathrm{C}$. Brazing time at a temperature above $577{ }^{\circ} \mathrm{C}$ was in the range of $5 \div 6 \mathrm{~min}$. The final stage of the process was cooling of the specimens in a controlled atmosphere at a speed of 40 to $50{ }^{\circ} \mathrm{C} / \mathrm{min}$.

\section{Results and discussions}

Preliminary metallographic tests of brazed joints were carried out using a light microscope (LM), type NIKON Eclipse LV150. Metallographic specimens were observed after their chemically etching with $0.5 \%$ HF acid solution. Cross-sections of the tested brazed joints of the wedge test were shown in Figure 4 .
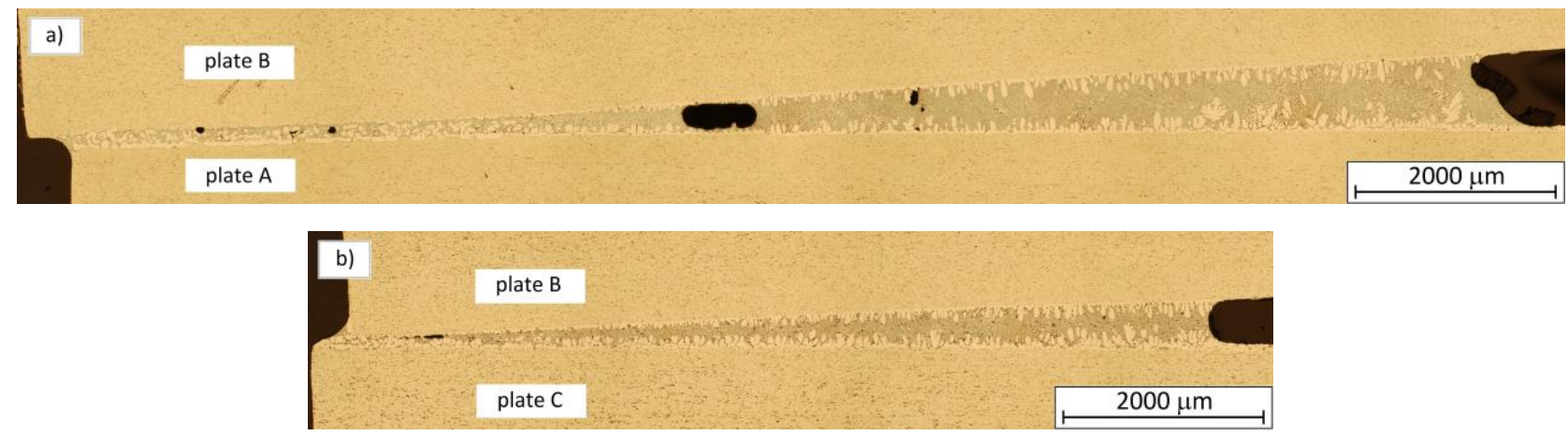

Fig. 4. Wedge test of the joints A-B (a) and C-B (b), chemically etched with $0.5 \%$ HF acid

The total length of brazing joint for both wedge tests was $13.88 \mathrm{~mm}$ (A-B joint) and $8.8 \mathrm{~mm}$ (C-B joint), respectively. The observed differences result from the use of various types of filler metals. For the A-B wedge test, was used the AlSi10 filler metal with a lower melting point in comparison to the AlSi7.5 filler metal used in the C-B wedge test. This difference, as well as the brazing properties of the filler metals, had a significant impact on the different filling of the wedge gap. This has been confirmed in a number of brazing experiments.

The width of the brazing gap has a decisive impact on the occurrence of the basic phenomenon of capillarity in the brazing process. In the wedge test, the width of the gap at the end of the A-B brazed joint was $772 \mu \mathrm{m}$, and for the C-B joint - $513 \mu \mathrm{m}$. Both filler metals filled the non-capillary gap, above $0.5 \mathrm{~mm}$. For the A-B wedge specimen, a filling for a wider gap in relation to C-B was obtained. On the one hand, this may be due to better wetting conditions of the surfaces to be joined during brazing, since the core material A does not contain $\mathrm{Mg}$ in compared to material $\mathrm{C}$. On the other hand, the low-melt filler metal AlSi10 used for material A has melted in a larger volume compared to material C where filler metal AlSi7.5 with higher melting point was used under the same temperature conditions.

In both brazed joints brazing minor incompatibilities occurred, in the form of a lack of continuity in the brazing joint, gas pores and post-flux slag inclusions. However, they do not constitute a significant reduction in the functionality of the brazed joint.

Carried out microscopic examinations (Figs. $5 \div 7$ ) showed in the brazing joint the occurrence of a typical subeutectic silumin microstructure, containing $\alpha$ phase grains and a needle-shaped eutectic mixture $(\alpha+\mathrm{Si})[8,9]$. 

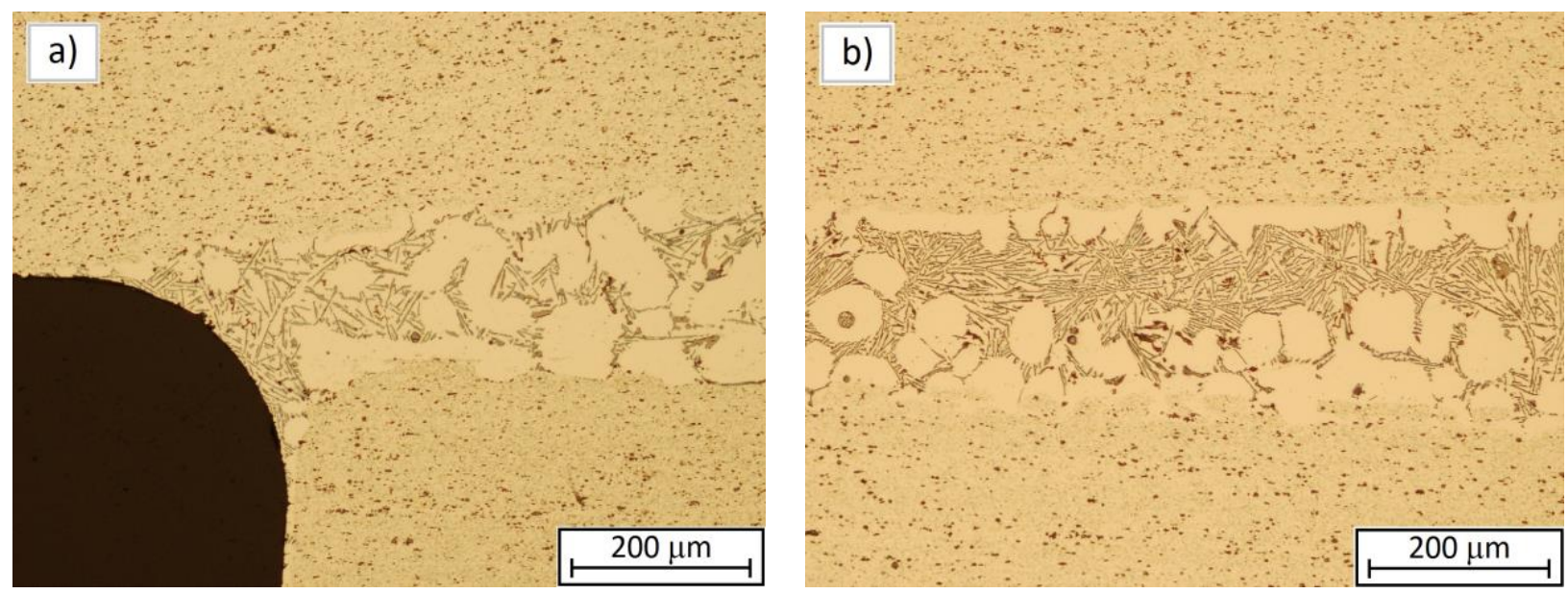

Fig. 5. Microstructure of wedge test joints, with a gap $150 \mu \mathrm{m}$ : joint A-B (a), joint C-B (b), chemically etched with $0.5 \%$ HF acid solution
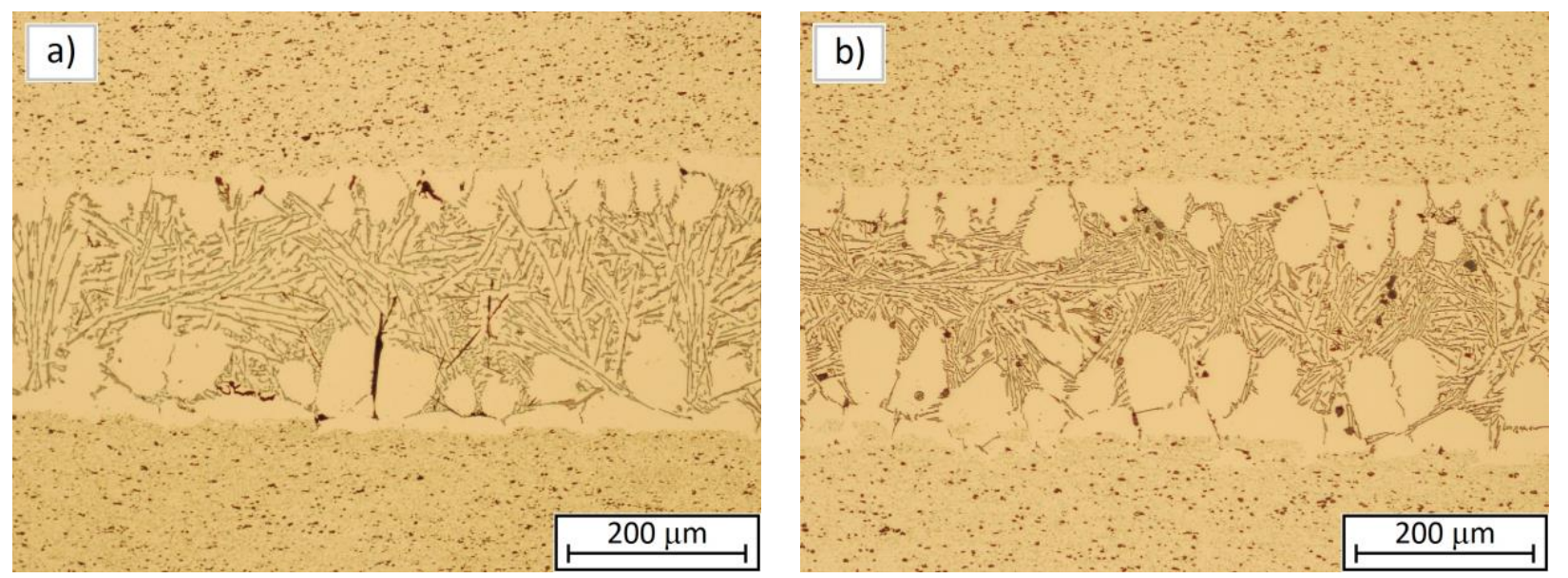

Fig. 6. Microstructure of wedge test joints, with a gap $300 \mu \mathrm{m}$ : joint A-B (a), joint C-B (b), chemically etched with $0.5 \%$ HF acid solution
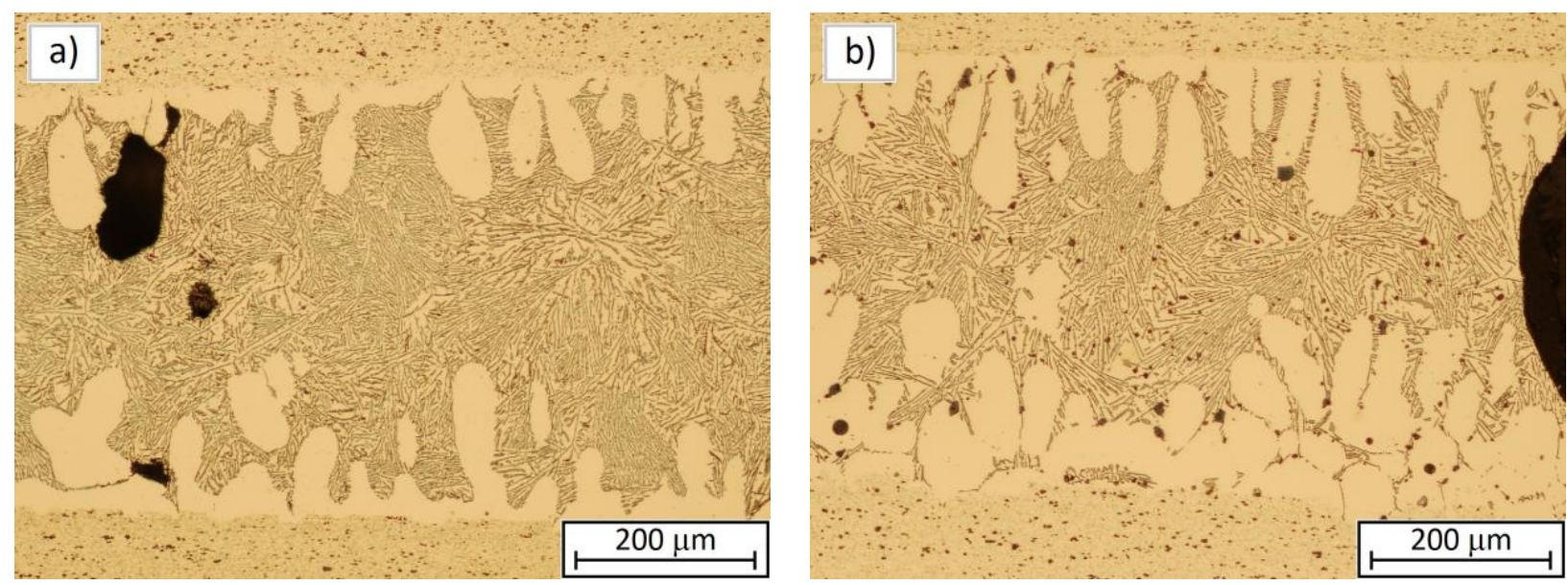

Fig. 7. Microstructure of wedge test joints, with a gap $500 \mu \mathrm{m}$ : joint A-B (a), joint C-B (b), chemically etched with $0.5 \%$ HF acid solution

In the $150 \mu \mathrm{m}$ gap, for the A-B joint, solid silicon solution precipitates was released over the entire width of the brazing joint (Fig. 5a) [10]. In the case of the C-B joint, with the same joint width and for both joints in the $300 \mu \mathrm{m}$ joint, a greater number of $\alpha$-phase precipitates are visible from the side of the material that was cladded with the filler metal (bottom plate) - Figures 5b, 6a and 6b. In a wider gap of $500 \mu m$, the size of the solid silicon solution precipitates is comparable both on the side of the cladded material and without it, for both joints (Fig. 7). Globular $\alpha$-phase grains occur in the gap of a small width of $150 \mu m$, while as the gap width increases, especially for the value of $500 \mu \mathrm{m}$, the columnar $\alpha$ phase precipitations are noticeable, which expand in the direction of the heat dispersal $[8,11]$. In the C-B joint, for smaller gap 
widths, i.e. 150 and $300 \mu \mathrm{m}$ (Fig. $5 \mathrm{~b}$ and $6 \mathrm{~b}$ ), a more concentrated, needle-shaped eutectic mixture can be observed compared to the A-B joint.

Microhardness measurements of brazed joints were made using the Vickers method with a penetrator load of 50 G, according to EN ISO 6507-1: 2018-05, using a Micro Vickers Hardness Tester HVS-1000 from Sinwon. The diagram of HV 0.05 microhardness measurements in specific areas of the brazed joint of the A-B wedge test is shown in Figure 8, and exemplary of the microhardness distribution in the A-B connection is shown in Figure 9.

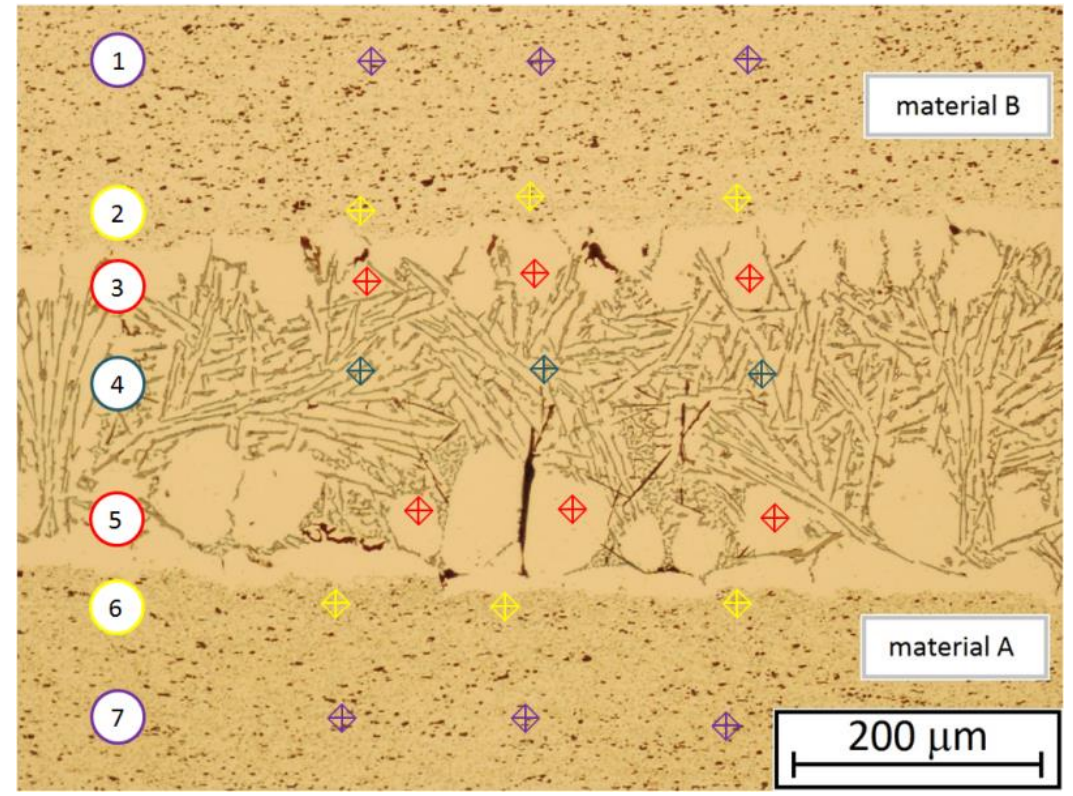

Fig. 8. Diagram of microhardness measurements HV 0.05 in the wedge test A-B, for gap $300 \mu \mathrm{m}$ : non-cladded material (1), subsurface layer of non-cladded material (2), precipitations of a solid silicon solution in aluminum ( $\alpha$ phase) from the material side without a clad (3), center of brazed joint( 4), precipitations of a solid silicon solution in aluminum ( $\alpha$ phase) from the material side with a clad (5), subsurface layer of cladded material (6), cladded material (7)

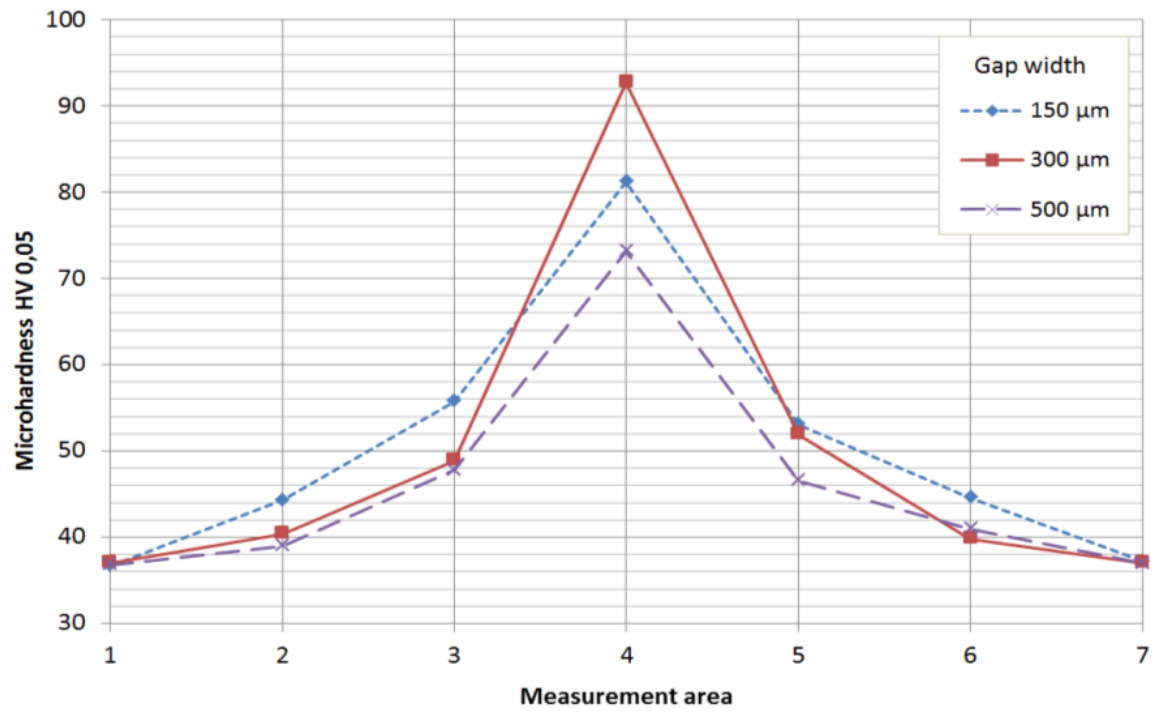

Fig. 9. Microhardness HV 0.05 distribution in brazed joint of wedge test A-B

The results obtained are the average of 3 measurements. The hardness of the core materials AlMn1Cu and AlMn1CuMg0.05 was in the range 37 $\div 40$ HV0.05 - the measured values are slightly lower than those given in [12]. The highest microhardness of 93 HV0.05 was measured in area 4 (eutectic needle-shaped precipitations), for a gap width of $300 \mu \mathrm{m}$ (Fig. 6a). The microhardness in zones with precipitation of solid solution of silicon in aluminum (phase $\alpha$ ), regardless of whether the material side was with or without clad, did not show significant deviations from each other and it was within the range of 48:53 HV0.05.

With a gap width of $0.15 \mathrm{~mm}$, a larger volume of brazing joint is occupied by phase $\alpha$, which is softer than the eutectic mixture. Therefore, given the huge brazing surface of aluminum heat exchangers, it is 
recommended to use a max. gap of $0.15 \mathrm{~mm}$ in the manufacturing process. This is confirmed by brazing of aluminum alloy heat exchangers using NOCOLOK technology, in which the recommended width of the brazing gap is equal to: 0.10 and $0.15 \mathrm{~mm}$. However, the recommended mounting gap are: for noncladded alloys between 0.10 and $0.15 \mathrm{~mm}$ and for cladded alloys (depending on the thickness of the binder layer) from 0.05 to $0.1 \mathrm{~mm}$ [7]. In the case of non-clad alloys bonding, additional filler metal application is required close to the joint, which can be carried out using a brazing ring, brazing paste or NOCOLOK flux with the additive of silicon (NOCOLOK Sil Flux) [7,13].
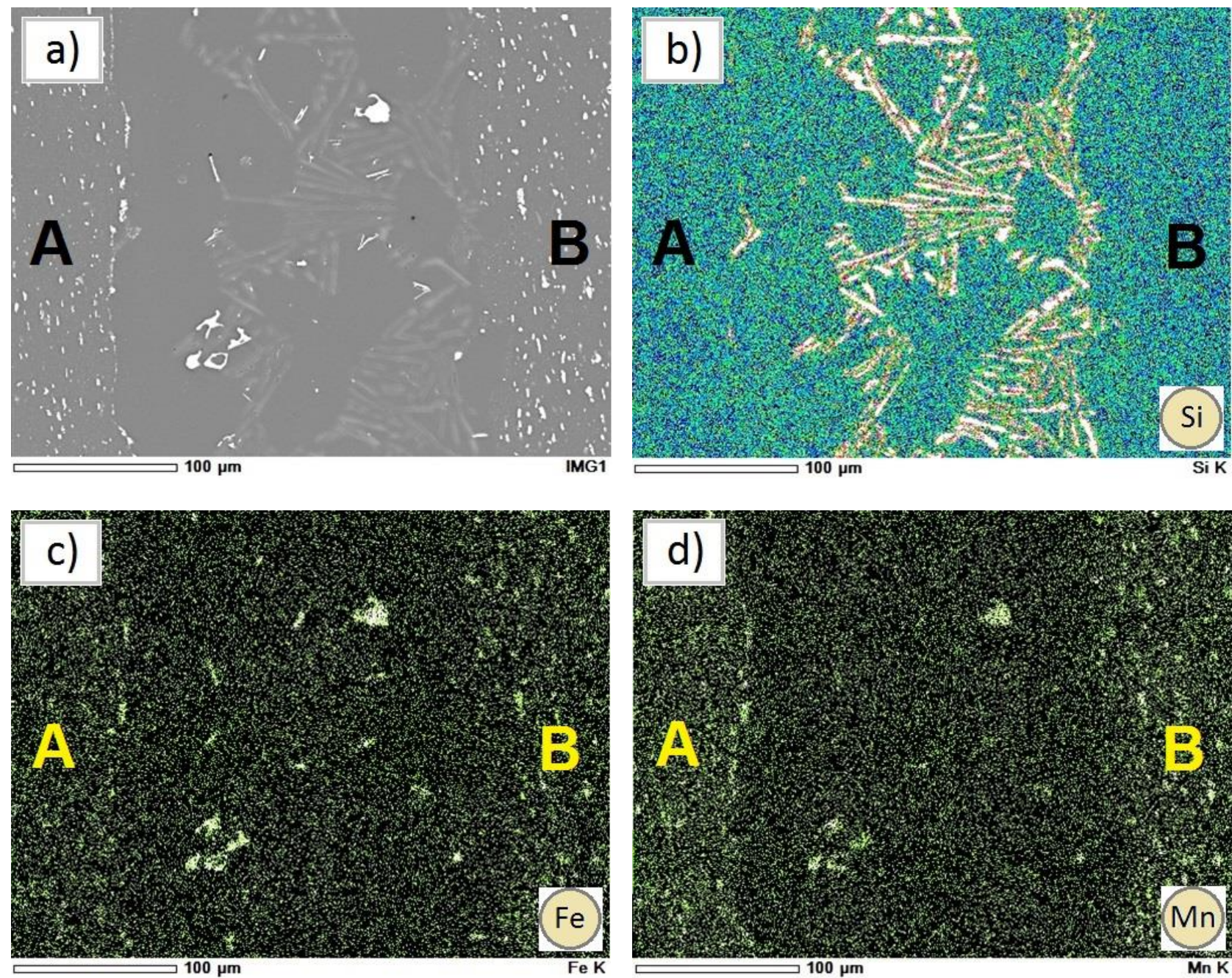

Fig. 10. Surface of metallographic specimen of A-B brazed joint, for a $300 \mu \mathrm{m}$ gap (a) and distribution maps of elements Si (b), Fe (c) and Mn (d), primary beam energy $20 \mathrm{keV}$, SEM

Tests of specimens was performed using a scanning electron microscope (SEM), model JSM6610A (JEOL) confirmed previous observations using a light microscope. Figure 10 shows the surface distribution of the basic elements found in the structure of the A-B brazed joint. The material contrast clearly shows the phase distribution containing elements heavier than $\mathrm{Al}$ and $\mathrm{Si}$, i.e. $\mathrm{Fe}$ and $\mathrm{Mn}$, found in the tested materials. Elemental distribution maps show that $\mathrm{Fe}$ and $\mathrm{Mn}$ are concentrated in precipitations occurring mainly in core materials and sporadically in brazing joint.

\section{Conclusions}

1. The wedge test showed the ability to fill by filler metal of the gap width more than $500 \mu \mathrm{m}$, for both of used filler metals AlSi10 and AlSi7.5, however higher fill occurred for the low-melt filler metal AlSi10.

2. The hardest area of the analyzed brazed joints is the eutectic precipitations zone. For a gap width of $300 \mu \mathrm{m}$, the microhardness in this zone was $93 \mathrm{HV} 0.05$. It is a zone almost twice as hard as compared to the precipitations of a solid solution of silicon in aluminum (phase $\alpha$ ). 
3. A cladding layer of filler metal, applied to only one brazed material, allows for proper wetting of the second material by liquid filler metal, although a slightly larger number of minor incompatibilities from the non-clad material side were observed.

4. It is recommended to use a maximum brazing gap of $150 \mu \mathrm{m}$ in the brazing process of aluminum heat exchangers. In this range, it is a capillary gap, in which the precipitation of $\alpha$ phase predominates, with a much lower hardness than the eutectic mixture $(\alpha+\mathrm{Si})$.

Author Contributions: conceptualization Z.M., J.P.; methodology J.P., J.H.; software, J.P.; validation J.P.; formal analysis Z.M., J.P.; investigation J.P., T.W., J.H.; resources J.P.; data curation J.P., T.W., J.H.; writing-original draft preparation J.P.; writing-review and editing Z.M., J.P.; visualization Z.M., J.P.; supervision Z.M., J.P.; project administration, Z.M., J.P.

Funding acquisition: This research received no external funding.

Conflicts of Interest: The authors declare no conflict of interest.

\section{References}

[1] Mirski Z., Pabian J., Modern trends in production of brazed heat exchangers for automotive industry. Welding Technology Review, 2017, Vol. 89(8), 5-12. https://doi.org/10.26628/ps.v89i8.798

[2] Controlled Atmosphere Aluminum Brazing Systems - SECO/WARWICK. Available online: https://www.secowarwick.com/wp-content/uploads/assets/Documents/Brochures/Controlled-Atm-AlumBrazing-Systems.pdf (accessed on 12-02-2020).

[3] Mirski Z., Granat K., Misiek A., Brazing of aluminum heat exchangers in the automotive industry. Spajanie materiałów konstrukcyjnych, 2015, Vol. 28(2), 32-34.

[4] Pilarczyk J. (editor), Engineer's Guide, Vol. 2, Welding., WNT: Warszawa, Poland, 2014,

[5] The NOCOLOK® Flux Brazing Process - Solvay Flux GmbH. Available online: https://www.solvay.com/sites/g/files/srpend221/files/tridion/documents/NOCOLOK-Brazing-Process-201802.pdf (accessed on 12-02-2020).

[6] Mirski Z., Control of the width of brazed joint clearance in the processes of joining dissimilar materials. Monography No 22, Prace Naukowe Instytutu Technologii Maszyn i Automatyzacji Politechniki Wrocławskiej, Wrocław, Poland, 2000.

[7] NOCOLOK® Encyclopedia - Solvay Flux GmbH. Available online: https://www.aluminium-brazing.com /sponsor/nocolok/Files/PDFs/NOCOLOK-Encyclopedia-2013.pdf (accessed on 12-02-2020).

[8] Wasilewski P., Silumines - modification and its influence on structure and properties, Monography No 21, Polish Academy of Sciences: Katowice, Poland, 1995.

[9] Velu P.K., Study of the effect of brazing on mechanical properties of aluminum alloys for automotive heat exchangers. Master's thesis, Purdue University, Purdue (IN), May 2017.

[10] Nylén M., Gustavsson U., Hutchinson W.B., Karlsson Å., Johansson H., Mechanisms of erosion during brazing of aluminium alloys. Materials Science Forum, 2002, Vol. 396-402, 1585-1590.

https://doi.org/10.4028/www.scientific.net/MSF.396-402.1585

[11] Nylén M., Gustavsson U., Hutchinson W.B., Örtnäs A., Mechanistic Studies of Brazing in Clad Aluminium Alloy. Materials Science Forum, 1996, Vol. 217-222, 1703-1708.

https://doi.org/10.4028/www.scientific.net/MSF.217-222.1703

[12] Iordache D.M., Ducu C.M., Niţu E.L., Iacomi D., Plăiaşu A.G., Preliminary study on the microstructure and mechanical properties of dissimilar joints of aluminum alloy and pure copper by FSW. MATEC Web of Conferences, 2017, Vol. 112, 1-6, 04005.

[13] Frąckowiak E., Mroziński W., Using flame brazing technology for producing aluminum automotive heat exchangers. Welding Technology Review, 2007, Vol. 79(9), 57-62.

(C) 2020 by the authors. Submitted for possible open access publication under the terms and conditions of the Creative Commons Attribution (CC BY) license (http://creativecommons.org/licenses/by/4.0/). 